園学雑. (J. Japan. Soc. Hort. Sci.) 50(4) : 521-531. 1982.

\title{
加工用トマト果実の静圧荷重抵抗性と堆積厚さ の許容限界について
}

\author{
伊藤 憲弘・寺田 俊郎 \\ (島根大学農学部)
}

The Load Resistivity to Static Pressure and the Permissible Limit

of Heaping Height on the Tomato Fruit for Processing

Norihiro Ito and Toshiro Terada

Faculty of Agriculture, Shimane University, Matsue, Shimane 690-11.

\section{Summary}

Load resistibility to static pressure and the permissible limit of heaping height were examined on the fruits of tomato for processing in order to rationalize a method for the handling of the fruits after harvest.

1. The behavior of fruits of static pressure resembled closely creep of fourelement model in the visco-elastic body.

2. The hardness and elastic behavior of the fruits were high in the cultivars of 'AT 70/24' 'TE-30' and 'ES-58'.

A high correlation was observed between the creep character and the color tone 'Hunter $\mathrm{a} / \mathrm{b}$ ratio) of the fruits with the significant level of $0.1 \%$, and the hardness and elastic behavior decreased with maturity.

3. The observed relations of the degree of fruit deformation to the magnitude of load and to the loading time showed that the extent of occurrence of lacerated wounds in the fruits was low in 'ES-58' 'TE-30' and 'AT 70/24' and high in 'H-1409' 'KG-127' and 'Kurikoma'. The limiting deformation rate beyond which the fruits were lacerated was highest (36.8\%) for 'AT-70/24' and lowest (7.5\%) for 'H-1409'.

4. The extent of fruit injury increased with an increase in heaping height of the fruits. Among the cultivars examined, 'H-1409' was injured most markedly, while 'TE-30' most slightly. The permissible limit of heaping height was very large for 'AT 70/24' 'ES-58' and 'TE-30' and low for 'H-1409' and 'KG-127'.

These observations indicate that the cultivars with high hardness and elastic behavior are also have the high load resistibility to static pressure. Among the cultivars examined, load resistibility to static pressure was very high for 'AT 70/24' 'TE-30' and 'ES-58'.

\begin{abstract}
緒言
一般に，ほ場で収穫されたトマト果実は直ちに加工工 場に搬入し，加工処理工程に移送することをたてまえと する．したがって原料受入れ後の保管は簡易屋根を有す る集積所か，集積群に雨よけのおおいをかぶせる程度 で，本格的な原料倉庫は使用されていない。しかし最盛 期には入荷が多く，滞荷現象となり，24〜43 時間太陽 の直射日光をあび，あるいは降雨にさらされる場合もあ る(14).なお, 輸送には $20 \mathrm{~kg}$ 入りプラスチック・コン 1981 年 6 月 5 日 受理
\end{abstract}

テナが用いられ，ほ場一集荷所一加工工場とトラック輸 送されているのが現状である。

昨今, 収檴段階における機械の開発研究が進みつつあ る.そこで，機械化の一貫した体系を考えてゆく上で， さらに収穫後の果実取り扱い法の合理化をはかることも 重要であろう。すなわち滞荷の解消, 貯蔵法の検討, 輸 送法の合理化などである。したがってアメリカなどでみ られる大型コンラナによる輸送，あるいは大型トレラー によるバラ積み輸送法などの実用化が今後の課題となる う. 
トマト果実はこのような収穫から加工処理工程に移送 するまでつあらゆる過程で多様な荷重を受け，それが果 実の損傷原因にもなっている。そしてこれらの果実損傷 は加工品つ品質低下はもとより，製造工程における洗浄 効率, トリミング効率つ著しい低下を招くことにもな る. 果実つ受ける損傷は直接果実が持つ特有の物理的性 質に左右される。すなわち振動衝撃，落下衝撃，あるい は圧縮や堆積による静圧荷重などに対する抵抗性などが 考えられる.

筆者らはさきにプランジャ圧縮による果実の貫入抵抗 力測定から果実の硬さについて，あるいは落下衝撃によ る損傷果の発生状況から落下許容限界などについて検討 し，その結果を報告した $(3,4)$. さらに本報では収穫後 の果実取り扱い, とくに貯蔵過程における静圧荷重下て の果実の挙動をとりあげた。すなわち静圧荷重下におけ る果実の抵抗性,および損傷果の発生からみた堆積厚さ の許容限界などについて検討したので報告する。

\section{材料及び方法}

実験は 1980 年 8 月に実施した。供試トマト果実は島 根大学農学部付属農場に括いて栽培されたものから採取 した.

供試品種は前報（3)を参考に，果実の形状，大きさの 点で特徵を有する品種, 系統を考慮して選定した.

試料つ熟度は前報 (2)に準じ，果実の着色状態をもつ て判定した. 判定は直読デジタル測色色差計（日本電色 工業製，ND-504DE）を用いた。

試料はまず色感によって熟度を 5 段階 $(I \sim V)$ に区 分し，それぞれの色調は等色差表色系により，a/b 值を もって表示した.なお， I，II，II は赤熟果， $\mathrm{N}, \mathrm{V}$ は熟 果に属し, 熟果は各品種とも $\mathrm{a} / \mathrm{b}$ 值 1.2 以上を示した.

果実の形態的性質は形状, 重量, 体積, 比重, および 子室数について測定し，その方法は前報 $(3,4)$ に準じた.

\section{1. クリープ及び復元試験}

果実の静圧荷重に対する力学的特性を知るため, クリ 一プ及び復元試験を行った.

荷重処理は果実の側部及び果頂部の 2 方向から実施し た。

供試品種は側部の場合, 洋ナシ型品種の ‘Chico’ 'Super Roma VF', 長型品種の 'San Marzano’ ‘AT 70/ 24'，丸型品種の ‘〈りこ屯’ ‘TE-30' 'KG-127', 偏円 型品種の 'ES-58' 'VF-145' 'H-1409' ‘カゴ メ 70'の 11 品種で, 果頂部の場合, ‘くりこま’ ‘TE-30’ 'KG127' 'ES-58' 'VF-145’ 'H-1409' ‘カゴメ 70’ の 7 品種 を用いた。なお，供試個体は各品種とも，25 個体（未 熟果 15, 熟果 10）とした.
測定法は石橋ら(1)，河野ら(6)，小島(8)の報告を参 考とした。すなわち試験機は万能引張り試験機（東洋ボ ールドウィン製，テンシロンUTM-II-20）に設置した クリープテストアダプタを用いて行った。

荷重は平板による重直定荷重とし，ロードセル（共和 電業製，LU-10 KA）で検出し，自動平衡指示計（東洋 ボールドウィン製，SS-8D）で一定に制御した.

設定した静圧荷重は $2 \mathrm{~kg}$ ，負荷時間は 7 分とし，そ の荷重下における果実の変形量を記録した，次いで荷重 を除去（測定は $0.1 \mathrm{~kg}$ ）した後， 5 分間，変形の復元状 態を测定した。

測定時の果実温度は測定に供した果実が前日に収穫さ れ，1 日室内貯蔵されたものであったことから，供試個 体間に大きな差異はないものとして取扱った。なお，測 定時の室温は $28.5 \sim 31.0^{\circ} \mathrm{C}$ であった。

第 1 図は塑性要素を直列に含む 4 要素模型とそのクリ ープ曲線を示したものである。

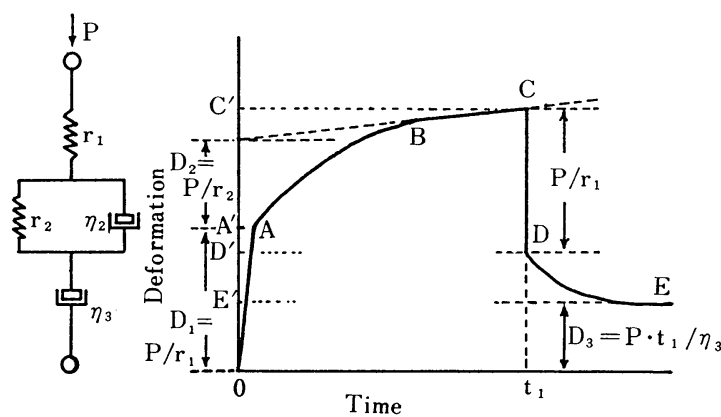

Fig. 1. Graphical and rheological models of creep and recovery test.

曲線 OABC は試料に一定荷重を加えた場合の変形量 の経時変化である.

この曲線における時間と変形量の関係は次式で示され る(10).

$$
D_{(t)}=\frac{P}{r_{1}}+\frac{P}{r_{2}}\left(1-e^{-r_{2} \cdot t / \eta_{2}}\right)+\frac{P}{\eta_{3}} \cdot t
$$

ここで, $D:$ 変形量 $(\mathrm{mm}) . P$ : 荷重 $(\mathrm{kg}), r_{1}, r_{2}$ : バネ定数 $(\mathrm{kg} / \mathrm{mm}), \eta_{2}, \eta_{3}$ : 粘性係数 $(\mathrm{kg} \cdot \mathrm{h} / \mathrm{mm}), t$ : 時間 ( h ).

右辺第 1 項は瞬間的弾性変形 (OA), 第 2 項は遅延弾 性変形 $(\mathrm{AB})$ ，第 3 項は粘性流動（BC）であるそここで $\mathrm{OA}^{\prime}$ を瞬間弾性変形量 (以下, 瞬間変形量と言う), 負 荷 7 分後における変形量 $\mathrm{OC}^{\prime}$ を全変形量とした。

なお，バネ定数 $r_{1}$ はマグネステーラ型の硬度計で得 られる硬さに相当するものである．したがって $r_{1}$ の大 きいものほど硬く，その值は(1)式より導びかれた次式に 
よって求められる(6).

$$
r_{1}=\frac{P}{D_{1}}
$$

曲線 $\mathrm{CDE}$ はある時刻 $t_{1}$ で荷重を取り除いた後，変 形の回復過程を示すものである.そしてその関係は次式 で示される(10).

$$
D_{(t)}=\frac{P}{r_{2}}\left(1-e^{-r_{2} \cdot t / \eta_{2}}\right) e^{-r_{2} / \eta_{2}\left(t-t_{1}\right)}+\frac{P}{\eta_{3}} \cdot t_{1}
$$

この場合, $\mathrm{CD}$ は瞬間弾性変形の回復量（以下，瞬間 回復量と言 ら) である。また，負荷除去 5 分後の変形回 復量 $\mathrm{C}^{\prime} \mathrm{E}^{\prime}$ を全回復量とした。なお，この回復過程には クリープ回復が完全ではなく, 永久に回復しない変形量 $\mathrm{OE}^{\prime}$ を残す，そこでこれを残留変形量として取扱った。 この残留変形量は荷重による变形のうち $\eta_{3}$ の動いた分 に相当する. したがって粘性係数 $\eta_{3}$ は(3)式より導びか れた次式によって求められる.

$$
\eta_{3}=\frac{P \cdot t_{1}}{D_{3}}
$$

変形率は試料の果径 (荷重方向側部の場合は横径, 果 頂部の場合は繸径) に対する变形量の比率をもって示し た.また，回復率は全変形量に対する回復量の比率をも って表した.

\section{2. 荷重の大きさ, 負荷時間と果実の変形量}

供試品種は 'Chico' 'Super Roma VF' 'San Marzano' 'AT 70/24' ‘くりこま' ‘TE-30' 'KG-127' 'ES58' ‘VF-145’ 'H-1409' ‘カゴメ 70’の 11 品種を用い, 各品種とも熟果のみを供試した.

供試個体は各品種 21 個体とし，それぞれ荷重処理に 先立ち果径を測定した.

荷重処理は荷重の大きさ別に 3 果ずつ供試し, 三星紋 状にならべた. そしてその上へ 1 辺 $300 \mathrm{~mm}$, 厚さ $20 \mathrm{~mm}$ の正三角形木製合板を乗せ，さらに合板の中央部には重 錘を置いた。荷重の大きさは合板と重錘を加えた重量で あり， $1.5,3.0,4.5,6.0,7.5,9.0,12.0 \mathrm{~kg}$ (1 果当 たりの荷重はそれぞれ $1 / 3$ になる)の 7 段階で実施した.

荷重処理方向はできれば果頂部, 側部の両方向で調查 すべきであるが，今回は品種ごとに果実の安定した定置 姿勢を保つ方向を選定した. すなわち洋ナシ型, 長型品 種では側部, 丸型, 偏円型品種では果頂部方向である. 変形率は荷重処理中, 一定時間ごとに果径の変化率を測 定し, 処理前の果径との比率をもって示した.

\section{3. バラ積みによる堆積厚さと果実の損傷}

果実のバラ積みにおける堆積厚さの差と損傷果の発生 状態を調査した。

堆積処理はプラスチック製 $20 \mathrm{~kg}$ 入りコンテナ (48.5 $\mathrm{cm} \times 32.0 \mathrm{~cm} \times 30.0 \mathrm{~cm})$ 及び木製箱 $(45.0 \mathrm{~cm} \times 45.0 \mathrm{~cm}$ $\times 100 \mathrm{~cm})$ を用いて行った。堆積時間はそれぞれ 24 時 間とした。

供試品種はプラスチック・コンテナの場合, 前述の実 験で用いたのと同じ 11 品種，木製箱の場合，'H-1409' 'KG-127' ‘カゴメ 70' 'TE-30' 'Super Roma VF'の 5 品種である.なお，各品種とも熟果のみを供試した。

供試個体は各品種 20 個体とし，プラスチック・コン テナの場合，堆積荷重が果実の側部及び果頂部から加わ るようにそれぞれ 10 個体ずつ, コンテナ底部に設置し た。なお，木製箱の場合は荷重方向を特別に考慮せず， 自然の堆積状態で処理した。

堆積厚さは木製箱の場合, $50,75,100 \mathrm{~cm}$ とし, コン テナの場合は底部である。

調査における損傷果の区分は前報(4)に準じた。すな わち第 1 表に示すように, 形状不変, 圧縮変形, 内部損 傷, 裂開損傷, 形状崩壊とし, それぞれ $0 \sim 8$ の損傷指 数をもって表示した.

Table 1. Classification of damaged fruits.

\begin{tabular}{c|l}
\hline D. I. & Description \\
\hline 0 & Externally unchanged fruit \\
\hline 1 & Deformation of fruit shape (small) \\
\hline 2 & De?ormation of fruit shape (large) \\
\hline 3 & Damage of internal tissue (small) \\
\hline 4 & Damage of internal titssue (large) \\
\hline 5 & Laceration (small) \\
\hline 6 & Laceration (medium) \\
\hline 7 & Laceration (large) \\
\hline 8 & Collapse of fruit shape
\end{tabular}

D. I.: Damage index

\section{結 果}

\section{1. クリープ及び復元試験}

トマト果実を堆積するとき，底に近い果実にはクリー

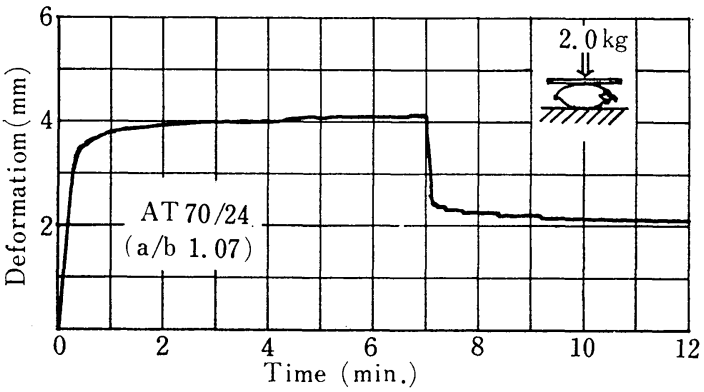

Fig. 2. A recording example of creep and recovery test. 
プに似た現象がみられる。

曲線における時間と変形量の関係は第 1 図に示すよう

第 2 図はトマト果実に平板を介して定荷重をかけ，あ な粘弾性体のうち 4 要素模型のクリープ現象に酷 似し る一定時間の後, その荷重を除去した時に得られる果実た。

の変形量を示す曲線である.

（1）品種別クリープ特性

Table 2. Result of creep and recovery test on tomato fruits classified by cultivar and maturity (Flank).

\begin{tabular}{|c|c|c|c|c|c|c|c|c|c|c|c|c|c|}
\hline \multirow{2}{*}{ Cultivar } & \multirow{2}{*}{$\mathrm{My}^{2}$} & \multicolumn{2}{|c|}{$\begin{array}{l}\text { Instantaneous } \\
\text { deformation }\end{array}$} & \multicolumn{2}{|c|}{$\begin{array}{c}\text { Total } \\
\text { deformation }\end{array}$} & \multicolumn{2}{|c|}{$\begin{array}{l}\text { Instantaneous } \\
\text { recovery }\end{array}$} & \multicolumn{2}{|c|}{ Total recovery } & \multicolumn{2}{|c|}{ Elements $^{w}$} & \multicolumn{2}{|c|}{$\begin{array}{c}\text { Residual } \\
\text { deformation }\end{array}$} \\
\hline & & $\begin{array}{l}\text { Quan- } \\
\text { tity }\end{array}$ & $\begin{array}{l}\text { Mod- } \\
\text { ulus }\end{array}$ & $\begin{array}{l}\text { Quan- } \\
\text { tity }\end{array}$ & $\begin{array}{l}\text { Mod- } \\
\text { ulus }\end{array}$ & $\begin{array}{l}\text { Quan- } \\
\text { tity }\end{array}$ & $\begin{array}{l}\text { Mod- } \\
\text { ulus }\end{array}$ & $\begin{array}{c}\text { Quan- } \\
\text { tity }\end{array}$ & $\begin{array}{l}\text { Mod- } \\
\text { ulus }\end{array}$ & $r_{1}$ & $\eta_{3}$ & $\begin{array}{l}\text { Quan- } \\
\text { tity }\end{array}$ & $\begin{array}{l}\text { Mod- } \\
\text { ulus }\end{array}$ \\
\hline Chico & $\begin{array}{l}\mathrm{im}^{\mathrm{y}} \\
\mathrm{ma}\end{array}$ & $\begin{array}{r}\mathrm{mm} \\
5.47 \\
10.79\end{array}$ & $\begin{array}{l}12 \% \\
12.8^{\%} \\
24.3\end{array}$ & $\begin{array}{r}\mathrm{mm} \\
6.71 \\
13.17\end{array}$ & $\begin{array}{c}\% \\
15.6 \\
29.6\end{array}$ & $\begin{array}{l}\quad \mathrm{mm} \\
2.25 \\
2.24\end{array}$ & $\begin{array}{r}\% \\
36.07 \\
17.19\end{array}$ & $\begin{array}{l}\quad \mathrm{mm} \\
2.63 \\
2.91\end{array}$ & $\begin{array}{r}\% \\
42.13 \\
22.29\end{array}$ & $\begin{array}{l}0.44 \\
0.19\end{array}$ & $\begin{array}{l}4.69 \\
1.44\end{array}$ & $\begin{array}{r}\mathrm{mm} \\
4.09 \\
10.26\end{array}$ & $\begin{array}{c}\% \\
9.6 \\
23.1\end{array}$ \\
\hline Super Roma VF & $\operatorname{im}_{\mathrm{ma}^{\mathrm{x}}}$ & $\begin{array}{r}6.64 \\
10.61\end{array}$ & $\begin{array}{l}12.8 \\
25.0\end{array}$ & $\begin{array}{r}8.48 \\
13.89\end{array}$ & $\begin{array}{l}15.9 \\
29.6\end{array}$ & $\begin{array}{l}2.83 \\
1.62\end{array}$ & $\begin{array}{l}36.55 \\
12.50\end{array}$ & $\begin{array}{l}\text { 3. } 33 \\
2.30\end{array}$ & $\begin{array}{l}42.37 \\
17.55\end{array}$ & $\begin{array}{l}0.46 \\
0.19\end{array}$ & $\begin{array}{l}5.47 \\
1.48\end{array}$ & $\begin{array}{r}5.15 \\
11.59\end{array}$ & $\begin{array}{r}8.8 \\
23.9\end{array}$ \\
\hline San Marzano & $\mathrm{im}$ & $\begin{array}{l}4.81 \\
7.55\end{array}$ & $\begin{array}{l}12.8 \\
20.0\end{array}$ & $\begin{array}{l}6.09 \\
9.44\end{array}$ & $\begin{array}{l}16.1 \\
25.0\end{array}$ & $\begin{array}{l}2.33 \\
2.37\end{array}$ & $\begin{array}{l}39.07 \\
25.13\end{array}$ & $\begin{array}{l}2.96 \\
2.91\end{array}$ & $\begin{array}{l}45.86 \\
30.85\end{array}$ & $\begin{array}{l}0.44 \\
0.27\end{array}$ & $\begin{array}{l}4.78 \\
2.21\end{array}$ & $\begin{array}{l}3.13 \\
6.53\end{array}$ & $\begin{array}{r}8.7 \\
17.2\end{array}$ \\
\hline A T $70 / 24$ & $\mathrm{im}$ & $\begin{array}{l}2.92 \\
3.92\end{array}$ & $\begin{array}{r}7.7 \\
10.0\end{array}$ & $\begin{array}{l}3.55 \\
4.86\end{array}$ & $\begin{array}{r}9.3 \\
13.3\end{array}$ & $\begin{array}{l}1.43 \\
1.57\end{array}$ & $\begin{array}{l}41.02 \\
32.42\end{array}$ & $\begin{array}{l}1.68 \\
1.89\end{array}$ & $\begin{array}{l}48.43 \\
39.00\end{array}$ & $\begin{array}{l}0.75 \\
0.52\end{array}$ & $\begin{array}{l}8.63 \\
4.80\end{array}$ & $\begin{array}{l}1.87 \\
2.97\end{array}$ & $\begin{array}{l}4.6 \\
8.2\end{array}$ \\
\hline Kurikoma & $\begin{array}{l}\mathrm{im} \\
\mathrm{ma}\end{array}$ & $\begin{array}{l}4.15 \\
7.18\end{array}$ & $\begin{array}{r}8.3 \\
14.7\end{array}$ & $\begin{array}{l}5.23 \\
8.88\end{array}$ & $\begin{array}{l}10.5 \\
17.9\end{array}$ & $\begin{array}{l}2.03 \\
3.21\end{array}$ & $\begin{array}{l}39.45 \\
36.12\end{array}$ & $\begin{array}{l}2.41 \\
3.69\end{array}$ & $\begin{array}{l}43.61 \\
41.70\end{array}$ & $\begin{array}{l}0.55 \\
0.28\end{array}$ & $\begin{array}{l}5.95 \\
2.75\end{array}$ & $\begin{array}{l}2.82 \\
5.19\end{array}$ & $\begin{array}{r}5.6 \\
10.4\end{array}$ \\
\hline T E-30 & $\mathrm{im}$ & $\begin{array}{l}3.65 \\
5.35\end{array}$ & $\begin{array}{l}6.9 \\
9.7\end{array}$ & $\begin{array}{l}4.65 \\
6.70\end{array}$ & $\begin{array}{r}8.8 \\
12.3\end{array}$ & $\begin{array}{l}1.39 \\
1.56\end{array}$ & $\begin{array}{l}32.64 \\
23.28\end{array}$ & $\begin{array}{l}1.65 \\
1.95\end{array}$ & $\begin{array}{l}38.33 \\
29.18\end{array}$ & $\begin{array}{l}0.66 \\
0.38\end{array}$ & $\begin{array}{l}6.50 \\
2.98\end{array}$ & $\begin{array}{l}2.99 \\
4.75\end{array}$ & $\begin{array}{l}5.7 \\
8.7\end{array}$ \\
\hline K G-127 & $\mathrm{im}$ & $\begin{array}{l}5.38 \\
7.02\end{array}$ & $\begin{array}{l}13.3 \\
15.8\end{array}$ & $\begin{array}{l}6.77 \\
8.39\end{array}$ & $\begin{array}{l}16.7 \\
18.9\end{array}$ & $\begin{array}{l}2.30 \\
2.46\end{array}$ & $\begin{array}{l}35.93 \\
29.16\end{array}$ & $\begin{array}{l}2.67 \\
2.91\end{array}$ & $\begin{array}{l}41.62 \\
34.58\end{array}$ & $\begin{array}{l:l}0.40 \\
0.29\end{array}$ & $\begin{array}{l}4.12 \\
2.57\end{array}$ & $\begin{array}{l}4.07 \\
5.48\end{array}$ & $\begin{array}{l}10.2 \\
12.3\end{array}$ \\
\hline E S -58 & $\begin{array}{l}\mathrm{im} \\
\mathrm{ma}\end{array}$ & $\begin{array}{l}3.67 \\
5.65\end{array}$ & $\begin{array}{l}5.9 \\
8.8\end{array}$ & $\begin{array}{l}4.71 \\
6.98\end{array}$ & $\begin{array}{r}7.6 \\
11.2\end{array}$ & $\begin{array}{l}1.66 \\
1.98\end{array}$ & $\begin{array}{l}37.19 \\
28.51\end{array}$ & $\begin{array}{l}1.97 \\
2.39\end{array}$ & $\begin{array}{l}43.95 \\
34.39\end{array}$ & $\begin{array}{l}0.65 \\
0.36\end{array}$ & $\begin{array}{l}6.89 \\
3.09\end{array}$ & $\begin{array}{l}2.75 \\
4.59\end{array}$ & $\begin{array}{l}4.4 \\
7.4\end{array}$ \\
\hline V F -145 & $\begin{array}{l}\mathrm{im} \\
\mathrm{ma}\end{array}$ & $\begin{array}{l}4.54 \\
7.62\end{array}$ & $\begin{array}{r}7.6 \\
12.2\end{array}$ & $\begin{array}{l}5.80 \\
9.84\end{array}$ & $\begin{array}{r}9.7 \\
15.8\end{array}$ & $\begin{array}{l}2.13 \\
2.41\end{array}$ & $\begin{array}{l}38.43 \\
24.87\end{array}$ & $\begin{array}{l}2.53 \\
3.11\end{array}$ & $\begin{array}{l}45.52 \\
31.90\end{array}$ & $\begin{array}{l}0.50 \\
0.27\end{array}$ & $\begin{array}{l}5.25 \\
2.15\end{array}$ & $\begin{array}{l}3.27 \\
6.73\end{array}$ & $\begin{array}{r}5.5 \\
10.8\end{array}$ \\
\hline $\mathrm{H}-1409$ & $\begin{array}{l}\mathrm{im} \\
\mathrm{ma}\end{array}$ & $\begin{array}{l}3.92 \\
7.10\end{array}$ & $\begin{array}{r}6.0 \\
10.4\end{array}$ & $\begin{array}{l}4.85 \\
8.73\end{array}$ & $\begin{array}{r}7.4 \\
13.1\end{array}$ & $\begin{array}{l}1.80 \\
2.57\end{array}$ & $\begin{array}{l}38.07 \\
29.95\end{array}$ & $\begin{array}{l}2.08 \\
3.08\end{array}$ & $\begin{array}{l}44.15 \\
35.90\end{array}$ & $\begin{array}{l}0.57 \\
0.29\end{array}$ & $\begin{array}{l}5.98 \\
2.59\end{array}$ & $\begin{array}{l}2.77 \\
5.65\end{array}$ & $\begin{array}{l}4.2 \\
8.5\end{array}$ \\
\hline Kagome 70 & $\begin{array}{l}\mathrm{im} \\
\mathrm{ma}\end{array}$ & $\begin{array}{l}4.87 \\
6.84 \\
\end{array}$ & $\begin{array}{r}9.3 \\
12.9 \\
\end{array}$ & $\begin{array}{l}5.93 \\
8.14 \\
\end{array}$ & $\begin{array}{l}11.4 \\
15.6\end{array}$ & $\begin{array}{l}1.99 \\
2.33 \\
\end{array}$ & $\begin{array}{l}35.91 \\
28.58 \\
\end{array}$ & $\begin{array}{l}2.33 \\
2.77 \\
\end{array}$ & $\begin{array}{l}41.73 \\
33.93\end{array}$ & $\begin{array}{l:l}0.48 \\
0.29\end{array}$ & $\begin{array}{l}5.10 \\
2.59\end{array}$ & $\begin{array}{l}3.60 \\
5.37\end{array}$ & $\begin{array}{r}6.9 \\
10.2\end{array}$ \\
\hline \multirow{2}{*}{ L. S. D. } & $5 \%$ & 0.83 & 2.28 & 0.44 & 2.71 & 0.64 & 3.64 & 0.34 & 4.21 & 0.06 & 0.78 & 1.15 & 2.8 \\
\hline & $1 \%$ & 1.11 & 3.06 & 0.58 & 3.62 & 0.86 & 4.88 & 0.45 & 5.64 & 0.08 & 1.04 & 1.54 & 3.7 \\
\hline
\end{tabular}

$z$ Maturity y Immature fruit $x$ Mature fruit w Elements of four-element model

Table 3. Result of creep and recovery test on tomato fruits classified by culltivar and maturity (Top).

\begin{tabular}{|c|c|c|c|c|c|c|c|c|c|c|c|c|c|}
\hline \multirow{2}{*}{ Cultivar } & \multirow{2}{*}{$\mathrm{My}^{\mathrm{z}}$} & \multicolumn{2}{|c|}{$\begin{array}{l}\text { Instantaneous } \\
\text { deformation }\end{array}$} & \multicolumn{2}{|c|}{$\begin{array}{c}\text { Total } \\
\text { deformation }\end{array}$} & \multicolumn{2}{|c|}{$\begin{array}{l}\text { Instantaneous } \\
\text { recovery }\end{array}$} & \multicolumn{2}{|c|}{ Total recovory } & \multicolumn{2}{|c|}{ Elements $^{w}$} & \multicolumn{2}{|c|}{$\begin{array}{l}\text { Residual } \\
\text { deformation }\end{array}$} \\
\hline & & $\begin{array}{c}\text { Quan- } \\
\text { tity }\end{array}$ & $\begin{array}{l}\text { Mod- } \\
\text { ulus }\end{array}$ & $\begin{array}{l}\text { Quan- } \\
\text { tity }\end{array}$ & $\begin{array}{l}\text { Mod- } \\
\text { ulus }\end{array}$ & $\begin{array}{c}\text { Quan- } \\
\text { tity }\end{array}$ & $\begin{array}{l}\text { Mod- } \\
\text { ulus }\end{array}$ & $\begin{array}{c}\text { Quan- } \\
\text { tity }\end{array}$ & $\begin{array}{l}\text { Mod- } \\
\text { ulus }\end{array}$ & $r_{1}$ & $\eta_{3}$ & $\begin{array}{r}\text { Quan- } \\
\text { tity }\end{array}$ & $\begin{array}{l}\text { Mod- } \\
\text { ulus }\end{array}$ \\
\hline Kurikoma & $\mathrm{im}^{\mathrm{y}}$ & $\begin{array}{l}\quad \mathrm{mm} \\
3.25 \\
5.25\end{array}$ & $\begin{array}{c}6 . \% \\
6.3^{\circ} \\
11.9\end{array}$ & $\begin{array}{l}\quad \mathrm{mm} \\
3.89 \\
6.59\end{array}$ & $\begin{array}{r}\% \\
7.8^{\circ} \\
14.7\end{array}$ & $\begin{array}{l}\quad \mathrm{mm} \\
1.35 \\
2.28\end{array}$ & $\begin{array}{r}\% \\
35.81 \\
34.54\end{array}$ & $\begin{array}{l}\mathrm{mm} \\
1.60 \\
2.72\end{array}$ & $\begin{array}{r}\% \\
43.02 \\
41.26\end{array}$ & $\begin{array}{l}0.78 \\
0.37\end{array}$ & $\begin{array}{l}8.12 \\
3.61\end{array}$ & $\begin{array}{l}\quad \mathrm{mm} \\
2.30 \\
3.87\end{array}$ & $\begin{array}{l}\% \\
4.6 \\
8.6\end{array}$ \\
\hline TE-30 & im & $\begin{array}{l}2.56 \\
3.95\end{array}$ & $\begin{array}{l}4.9 \\
6.9\end{array}$ & $\begin{array}{l}3.26 \\
5.02\end{array}$ & $\begin{array}{l}6.2 \\
8.8\end{array}$ & $\begin{array}{l}0.93 \\
1.11\end{array}$ & $\begin{array}{l}30.47 \\
22.39\end{array}$ & $\begin{array}{l}1.14 \\
1.42\end{array}$ & $\begin{array}{l}37.13 \\
28.58\end{array}$ & $\begin{array}{l}0.88 \\
0.53\end{array}$ & $\begin{array}{l}8.17 \\
4.05\end{array}$ & $\begin{array}{l}2.12 \\
3.60\end{array}$ & $\begin{array}{l}4.1 \\
6.3\end{array}$ \\
\hline $\mathrm{KG}-127$ & im & $\begin{array}{l}4.44 \\
6.41\end{array}$ & $\begin{array}{r}9.2 \\
13.2\end{array}$ & $\begin{array}{l}5.57 \\
8.01\end{array}$ & $\begin{array}{l}11.7 \\
16.5\end{array}$ & $\begin{array}{l}1.65 \\
2.45\end{array}$ & $\begin{array}{l}32.18 \\
30.67\end{array}$ & $\begin{array}{l}1.99 \\
2.92\end{array}$ & $\begin{array}{l}38.49 \\
36.52\end{array}$ & $\begin{array}{l}0.51 \\
0.32\end{array}$ & $\begin{array}{l}4.90 \\
2.80\end{array}$ & $\begin{array}{l}3.58 \\
5.09\end{array}$ & $\begin{array}{r}7.5 \\
11.8\end{array}$ \\
\hline ES-58 & im & $\begin{array}{l}2.08 \\
3.72\end{array}$ & $\begin{array}{l}4.2 \\
7.1\end{array}$ & $\begin{array}{l}2.65 \\
4.63\end{array}$ & $\begin{array}{l}5.3 \\
9.0\end{array}$ & $\begin{array}{l}0.91 \\
1.34\end{array}$ & $\begin{array}{l}34.75 \\
28.85\end{array}$ & $\begin{array}{l}1.09 \\
1.65\end{array}$ & $\begin{array}{l}41.87 \\
35.61\end{array}$ & $\begin{array}{l}1.06 \\
0.64\end{array}$ & $\begin{array}{r}10.12 \\
5.49\end{array}$ & $\begin{array}{l}1.55 \\
2.98\end{array}$ & $\begin{array}{l}3.1 \\
5.8\end{array}$ \\
\hline VF-145 & im & $\begin{array}{l}3.33 \\
5.43\end{array}$ & $\begin{array}{r}6.2 \\
10.4\end{array}$ & $\begin{array}{l}4.19 \\
6.98\end{array}$ & $\begin{array}{r}7.9 \\
13.3\end{array}$ & $\begin{array}{l}1.31 \\
1.83\end{array}$ & $\begin{array}{l}33.67 \\
26.39\end{array}$ & $\begin{array}{l}1.60 \\
2.30\end{array}$ & $\begin{array}{l}40.80 \\
33.16\end{array}$ & $\begin{array}{l}0.82 \\
0.38\end{array}$ & $\begin{array}{l}8.28 \\
3.11\end{array}$ & $\begin{array}{l}2.59 \\
4.68\end{array}$ & $\begin{array}{l}4.9 \\
8.9\end{array}$ \\
\hline $\mathrm{H}-1409$ & im & $\begin{array}{l}2.67 \\
4.55\end{array}$ & $\begin{array}{l}5.2 \\
8.5\end{array}$ & $\begin{array}{l}3.29 \\
5.45\end{array}$ & $\begin{array}{r}6.4 \\
10.4\end{array}$ & $\begin{array}{l}0.93 \\
1.60\end{array}$ & $\begin{array}{l}30.05 \\
29.46\end{array}$ & $\begin{array}{l}1.13 \\
1.94\end{array}$ & $\begin{array}{l}36.45 \\
35.59\end{array}$ & $\begin{array}{l}0.88 \\
0.46\end{array}$ & $\begin{array}{l}8.22 \\
4.06\end{array}$ & $\begin{array}{l}2.16 \\
3.51\end{array}$ & $\begin{array}{l}4.2 \\
6.7\end{array}$ \\
\hline Kagome 70 & $\begin{array}{l}\mathrm{im} \\
\mathrm{ma}\end{array}$ & $\begin{array}{l}3.47 \\
5.59 \\
\end{array}$ & $\begin{array}{r}7.9 \\
13.2 \\
\end{array}$ & $\begin{array}{l}4.27 \\
6.79 \\
\end{array}$ & $\begin{array}{r}9.7 \\
16.1\end{array}$ & $\begin{array}{l}1.43 \\
2.02\end{array}$ & $\begin{array}{l}34.59 \\
29.90\end{array}$ & $\begin{array}{l}1.71 \\
2.47\end{array}$ & $\begin{array}{l}41.65 \\
36.55\end{array}$ & $\begin{array}{l}0.73 \\
0.36\end{array}$ & $\begin{array}{l}7.35 \\
3.23\end{array}$ & $\begin{array}{l}2.55 \\
4.32\end{array}$ & $\begin{array}{r}5.8 \\
10.3\end{array}$ \\
\hline L.S. D & $5 \%$ & 0.52 & 1.34 & 0.71 & 1.53 & 0.27 & 3.44 & 0.29 & 4.15 & 0.12 & 1.14 & 0.54 & 1.2 \\
\hline & $1 \%$ & 0.71 & 1.82 & 0.96 & 2.21 & 0.36 & 4.66 & 0.39 & 5.62 & 0.17 & 1.54 & 0.72 & 1.6 \\
\hline
\end{tabular}

${ }^{z}$ Maturity ${ }^{y}$ Immature fruit ${ }^{x}$ Mature fruit ${ }^{\text {w }}$ Elements of four-element model 
第 2 表，第 3 表はクリープ及び復元試験結果の品種間 差を示したものである.

第 2 表において果実側部方向から荷重を加觉た場合の 変形量を熟果でみると， 'Chico' 'Super Roma VF' が 最も大きく, 瞬間変形量 $10.8,10.6 \mathrm{~mm}$, 全変形量 13. $2,13.9 \mathrm{~mm}$ であった. 変形量の少ない品種は‘AT $70 / 24$ ' (瞬間変形量 $3.9 \mathrm{~mm}$, 全変形量 $4.9 \mathrm{~mm}$ ), 'TE30’ 'ES-58' であった.

変形率は瞬間変形率，全変形率ともに 'Chico' 'Super Roma VF' が大きく, ‘TE-30' 'ES-58' 'H-1409' ‘AT 70/24’に小さい傾向が認められた.

バネ定数 $r_{1}$ は 'AT 70/24' ‘TE-30' 'ES-58' が大き い值を示した.これはさきの貫入抵抗力測定 (3)におい ても，これらの品種が高い数值を示したことから考え て， $r_{1}$ の大きい品種ほど荷重に対してひずみにくく， 硬さは硬いと言える.すなわち河野らの報告(6) と同様 な結果が得られた。

荷重除去後の回復状況を熟果でみると, 瞬間回復率, 全回復率ともに ‘くりこま’ ‘AT 70/24’ が大きく, ‘Chico’'Super Roma VF’ が小さい数值を示した.

瞬間回復量は各品種とも瞬間变形量に比べて少ない傾 向を示した. したがって荷重除去後には永久に回復しな い変形量が残る。そこで荷重除去 5 分後の残留変形率を みると, 'Super Roma VF' 'Chico' が極端に大きく, 'ES-58' 'AT 70/24’ 'H-1409’ 'TE-30’が小さかった。

粘性係数 $\eta_{3}$ の值は 'AT 70/24' が最も大きく, 次い で 'ES-58’ ‘TE-30’であった. 逆に 'Chico' 'Super Roma VF'の值は小さかった。 すなわち $\eta_{3}$ の值が大き
い品種ほど荷重除去後に残る変形量は少ないと言える. ある物質が弾性的であるか非弾性的であるかは，応力 によって生じた弾性変形と永久変形の比できまる(10). したがって $\eta_{3}$ の值が大きい ‘AT 70/24’ ‘TE-30' 'ES58’は弾性的な品種であると考えられる.

第 2 表及び第 3 表の結果から, 荷重の加わる方向の差 異による果実の変形状態を丸型及び偏円型品種について 検討すると, 変形量, 回復量の值は側部が果頂部方向よ り幾分大きく, $r_{1}, \eta_{3}$ の数值は果頂部が大きい.すなわ ち果実は側部よりも果頂部が幾分硬く, 弾性的挙動を示 すものと考学られる. しかし荷重方向の差異にかかわら ず変形率，回復率はともに 'TE-30’ 'ES-58’ が小さく, 'KG-127’ ‘カゴメ70’くりこま’が大きい。また， $r_{1}, \eta_{3}$ の值は 'TE-30’'ES-58'が大きい結果を示した。

このことから丸型及び偏円型品種におけるクリープ特 性はある一方向の荷重下における測定值をもって代表さ れるよらにも考えられる。

（2）果実の形態的性質と変形

果実の形状, 果実重, 体積, 比重及び子室数とクリー プ試験結果の関係を示したのが第 4 表である.

果形指数と変形率, 回復率との間に相関関係は認めら れず，果実の形状からみた静圧荷重に対する変形量の相 違は確認できなかった。

果実重, 体積, 比重及び子室数と変形率との関係をみ ると，それぞれの間に負の相関関係が認められた。しか 乙果実重, 体積, 比重及び子室数と回復率との間に相関 関係は存在しなかった。 また，これらの形態的性質の調 査項目と $r_{1}, \quad \eta_{3}$ の間に相関関係を認めることができな

Table 4. Correlations between some physical properties and creep characters of fruit in all cultivars tested (Mature fruit, Flank).

\begin{tabular}{|c|c|c|c|c|c|c|c|}
\hline & \multirow{2}{*}{ I. D. M } & \multirow{2}{*}{ T.D.M } & \multirow{2}{*}{ I. R. M } & \multirow{2}{*}{ T.R.M } & \multicolumn{2}{|c|}{ Elements $^{z}$} & \multirow{2}{*}{ R. D. M } \\
\hline & & & & & $\eta_{1}$ & $\eta_{2}$ & \\
\hline Fruit shape ${ }^{y}$ & -0.530 & -0.527 & 0.297 & 0.297 & -0.184 & -0.164 & -0.505 \\
\hline Weight & $-0.700 *$ & $-0.686^{*}$ & 0.233 & 0.263 & 0.148 & 0.110 & $-0.609 *$ \\
\hline Volume & $-0.643^{*}$ & $-0.625^{*}$ & 0.141 & 0.180 & 0.095 & 0.045 & -0.539 \\
\hline Specific weight & $-0.848 * * *$ & $-0.852^{* * *}$ & 0.564 & 0.570 & 0.348 & 0.362 & $-0.822^{* * *}$ \\
\hline Locule $^{\mathrm{x}}$ & $-0.715^{*}$ & $-0.702^{*}$ & 0.305 & 0.332 & 0.126 & 0.105 & $-0.642^{*}$ \\
\hline
\end{tabular}

I. D. M : Instantaneous deformation modulus

T. D. M : Total deformation modulus

I. R. M : Instantaneous recovery modulus

T. R. M : Total recovery modulus

R.D. M : Residual deformation modulus

$z$ Elements of four-element model

y Fruit shape index $=\frac{\text { Diameter }}{\text { Length }}$

$x$ Number of locules

$*$,*** Significant at $5 \%$ and $0.1 \%$ level, respectively. 
Table 5. Correlations between Hunter a/b ratio and creep characters of fruit in each cultivar (Flank).

\begin{tabular}{|c|c|c|c|c|c|c|c|}
\hline \multirow{2}{*}{$1+i v a r$} & \multirow{2}{*}{ I. D. M } & \multirow{2}{*}{ T.D. M } & \multirow{2}{*}{ I. R. M } & \multirow{2}{*}{ T.R.M } & \multicolumn{2}{|c|}{ Elements $^{z}$} & \multirow{2}{*}{ R. D. M } \\
\hline & & & & & $r_{1}$ & $r_{1}$ & \\
\hline Chico & $0.836^{* * * *}$ & $0.897^{* * *}$ & $-0.918^{* * *}$ & $-0.917^{* * *}$ & $-0.841^{* * *}$ & $-0.833 * * *$ & $0.908^{* * *}$ \\
\hline Super Roma VF & $0.825^{* * *}$ & $0.826^{* * *}$ & $-0.939 * * *$ & $-0.935^{* * *}$ & $-0.858^{* * *}$ & $-0.883^{* * *}$ & $0.859 * * *$ \\
\hline San Marzano & $0.920^{k * *}$ & $0.908^{* * *}$ & $-0.887^{* * *}$ & $-0.896^{* * *}$ & $-0.869 * * *$ & $-0.872^{* * *}$ & $0.940^{* * *}$ \\
\hline AT $70 / 24$ & $0.792^{* * *}$ & $0.824 * * *$ & $-0.843^{* * *}$ & $-0.833^{* * *}$ & $-0.724^{* * *}$ & $-0.752^{* * *}$ & $0.875^{* * *}$ \\
\hline Kurikoma & $0 . \subseteq 04^{* * *}$ & $0.904^{* * *}$ & $-0.689^{* * *}$ & $-0.833^{* * *}$ & $-0.773^{* * *}$ & $-0.773^{* * *}$ & $0.915^{* * *}$ \\
\hline TE-30 & $0.703^{* * *}$ & $0.722^{* * *}$ & $-0.827^{* * *}$ & $-0.803^{* * *}$ & $-0.752^{* * *}$ & $-0.746^{* * *}$ & $0.751^{* * *}$ \\
\hline KG-127 & $0.667 * * *$ & $0.612^{* * *}$ & $-0.589 * *$ & $-0.596^{* *}$ & $-0.787^{* * *}$ & $-0.780^{* * *}$ & $0.597^{* *}$ \\
\hline ES-58 & $0.815^{* * *}$ & $0.791 * * *$ & $-0.786 * * *$ & $-0.828^{* * *}$ & $-0.698^{* * *}$ & $-0.670^{* * *}$ & $0.816^{* * *}$ \\
\hline VF-145 & $0.842^{* * *}$ & $0.818^{* * *}$ & $-0.907^{* * *}$ & $-0.892 * * *$ & $-0.810^{* * *}$ & $-0.832 * * *$ & $0.857^{* * *}$ \\
\hline H-1409 & $0.745^{* * *}$ & $0.984^{* * *}$ & $-0.781^{* * *}$ & $-0.807^{* * *}$ & $-0.864^{* * *}$ & $-0.847^{* * *}$ & $0.898 * * *$ \\
\hline Kagome 70 & $0.796 * * *$ & $0.802^{* * *}$ & $-0.825^{* * *}$ & $-0.829 * * *$ & $-0.815^{* * *}$ & $-0.803^{* * *}$ & $0.991 * * *$ \\
\hline
\end{tabular}

I. D. M : Instantaneous deformation modulus

T. D. M : Total deformation modulus

I. R. M : Instantaneous recovery modulus

T. R. M : Total recovery modulus

R. D. M : Residual deformation modulus

$z$ Elements of four-element model

**,*** Significant at $1 \%$ and $0.1 \%$ level, respectively.

Table 6. Correlations between Hunter $\mathrm{a} / \mathrm{b}$ ratio and creep characters of fruit in each cultivar (Top).

\begin{tabular}{l|l|l|l|l|l|l|l}
\hline \hline \multicolumn{1}{c|}{ Cultivar } & I. D. M & T. D.M & I. R.M & T. R. M & \multicolumn{2}{|c|}{ Elements $^{2}$} & R. D. M \\
\hline Kurikoma & $0.904^{* * *}$ & $0.908^{* * *}$ & -0.257 & -0.239 & $-0.756^{* * *}$ & $-0.706^{* * *}$ & $0.818^{* * *}$ \\
TE-30 & $0.730^{* * *}$ & $0.745^{* * *}$ & $-0.843^{* * *}$ & $-0.788^{* * *}$ & $-0.787^{* * *}$ & $-0.794^{* * *}$ & $0.775^{* * *}$ \\
KG-127 & $0.854^{* * *}$ & $0.862^{* * *}$ & $-0.547^{* *}$ & $-0.559^{* *}$ & $-0.843^{* * *}$ & $-0.821^{* * *}$ & $0.828^{* * *}$ \\
ES-58 & $0.848^{* * *}$ & $0.912^{* * *}$ & $-0.673^{* * *}$ & $-0.665^{* * *}$ & $-0.829^{* * *}$ & $-0.860^{* * *}$ & $0922^{* * *}$ \\
VF-145 & $0.888^{* * *}$ & $0.882^{* * *}$ & $-0.846^{* * *}$ & $-0.829^{* * *}$ & $-0.806^{* * *}$ & $-0.781^{* * *}$ & $0.885^{* * *}$ \\
H-1409 & $0.904^{* * *}$ & $0.901^{* * *}$ & $-0.418^{*}$ & -0.396 & $-0.846^{* * *}$ & $-0.809^{* * *}$ & $0.853^{* * *}$ \\
Kagome 70 & $0.839^{* * *}$ & $0.829^{* * *}$ & $-0.759^{* * *}$ & $-0.716^{* * *}$ & $-0.748^{* * *}$ & $-0.746^{* * *}$ & $0.815^{* * *}$ \\
\hline
\end{tabular}

I. D. M : Instantaneous deformation modulus

T. D. M : Total deformation modulus

I. R. M : Instantaneous recovery modulus

T. R.M : Total recovery modulus

R. D. M : Residual deformation modulus

$z$ Elements of four-element model

$*, * *, * * *$ Significant at $5 \%, 1 \%$, and $0.1 \%$ level, respectively.

かった.

これらのことから果実の形態的性質とクリープ特性と の間に明確な関係を把握することはできなかった：しか し静圧荷重下における果実の変形率は子室数が多く, 果 実の大きい，比重の大きいものほど小さいと言える.乙 たがって子室数が少なく, 比重の小さい ‘Chico' 'Super Roma VF'の変形が大きく, 比重の大きい'ES-58' ‘TE30’'AT 70/24’などに変形量の少ないことが理解され る.

（3）果実成熟度の差異と変形

果実の色調とクリープ試験結果との関係から, 成熟度
の差異による果実の変形状態を第 3 図, 第 5 表及び第 6 表に示した。

第 3 図は ‘くりこまに’お打る熟度区分別のクリープ 曲線を示したものである。

果実が成熟するのに伴い瞬間変形量, 全変形量は順次 高く推移した。なお，図示は省略したが，このような傾 向は供試した全品種において確認された。すなわち第 5 表, 第 6 表に示したように, 熟度と変形率との関係は瞬 間変形率, 全変形率ともに $0.1 \%$ 水準下で正の相関関係 にあった。また, 熟度と $r_{1}$ との間には負の相関関係が 認められた。 


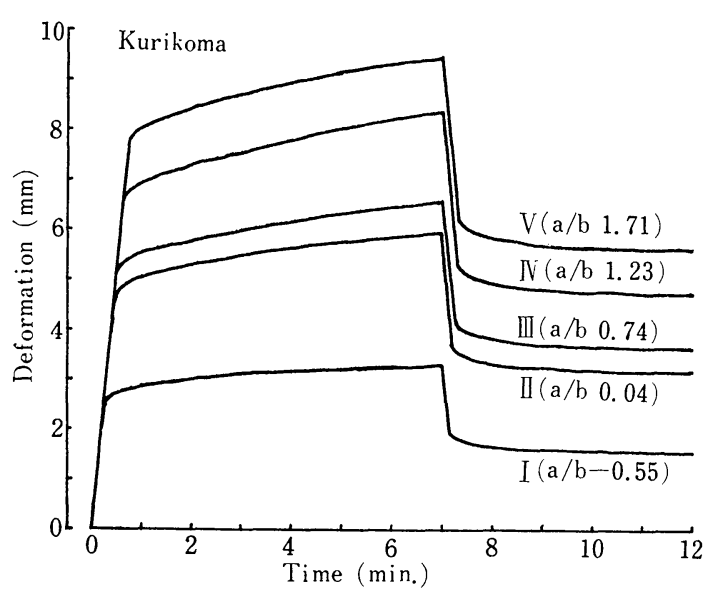

Fig. 3. Creep and recovery curves of the fruits in different stages of maturity (Flank).

このことは果実が成熟に伴い，漸次軟化することを意 味しており，前報の貫入抵抗力測定(3) と同様な結果が 得られた。

荷重除去後の変形回復状況をみると, 熟度と回復率及 び $\eta_{3}$ との間に高い負の相関関係が認められた．したが って残留変形率は全供試品種とも, 熟度との間に高い正 の相関関係があった.

これは果実が成熟に伴い，漸次回復率は小さくなり， ひいては弾性的挙動の低下することを意味している，乙 かし荷重方向果頂部の実験結果において‘くりこま’ ‘H一 1409’など, 成熟に伴う回復率低下の傾向が明確でない 品種も存在していた.したがってさらに詳細な調査が必 要であろう.

\section{2. 荷重の大きさ, 負荷時間と果実の変形量}

荷重の大きさ別にみた負荷時間と変形率との関係から 第 4 図に示すような一次の回帰直線が得られた.

果実の変形率は各品種とも，荷重の大きさにかかわら ず，負荷時間が長くなるほど増大した。すなわちクリー プ現象が認められた。なお，変形率は荷重の大きいほど 高い位置を推移し，時間に対する直線の勾配は急であっ た.

荷重の大きさに対する変形状沉を供試品種間でみる 之, 'Chico' 'Super Roma VF' 'San Marzano' ‘くり こま’ ‘KG-127’などの変形率が大きい傾向を示した. なお, ‘Chico’ 'Super Roma VF' 'San Marzano’ にお いては荷重方向が側部であったことも幾分影響している ものと考える.

変形率の小さい品種は 'ES-58' ‘TE-30’であり, 負 荷時間との直線勾配も緩慢であった。 また，'AT 70/24' は荷重方向が側部であったにもかかわらず, 変形率は比
較的低く推移した。

各荷重における裂開損傷の発生した負荷時間をみる と, 'KG-127' ‘くりこま' 'H-1409' が比較的早く裂開 損傷に達した.

荷重を加えた直後, 瞬時に裂開した品種及び荷重の大 きさは 'San Marzano’が $2.0 \mathrm{~kg}$ 以上, 'KG-127' 'Super Roma VF' 'H-1409’ が $2.5 \mathrm{~kg}$ 以上であった.な お，裂開損傷発生の低い品種は 'ES-58' ‘TE-30’ ‘AT $70 / 24$ ‘であった. すなわち本実験の最高荷重 $(4.0 \mathrm{~kg} /$ 個）を加觉た場合の裂開損傷発生の負荷時間は 'ES-58' で 50.5 時間, ‘TE-30’ で 32.7 時間, 'AT 70/24’ で 2.0 時間であった.

これらの結果から，さきのクリープ試験結果において 弾性的品種であろうと考えられた 'ES-58' ‘TE-30' ‘AT $70 / 24$ 'が静圧荷重に対する抵抗性の高い品種と見受けら れた。

\section{3. バラ積みによる堆積厚さと果実の損傷}

バラ積み堆積処理による果実の損傷程度を第 5 図, 第 6 図に示した.

第 5 図は現在貯蔵, 輸送に使用されているプラスチッ ク・コンテナを用い, $20 \mathrm{~kg}$ の果実を充填し， 24 時間放 置した後の調査結果である。

充填果実の堆積厚さは各品種 $22.0 \sim 25.0 \mathrm{~cm}$ であり, 品種間に顕著な差は認められなかった。

損傷損度は供試品種のなかで ‘H-1409’が最も大きく， 平均損傷指数值は 3〜4 を示した.これは内部組織がー 部破壊された押し傷の状態である. しかしその損傷程度 の変異は大きく,なかには果皮に裂傷の及ぶ果実も認め られた。

‘TE-30’の損傷程度は比較的低い傾向を示した.な お, その他の品種では全般に指数值 $2 \sim 3$ を示し, 顕著 な差は認められなかった。

荷重方向の差から損傷の程度をみると, 一部その傾向 を示さない品種はみられるものの, 一般に果頂部よりも 果実側部方向からの荷重に対して, 損傷は大きい傾向が みられた。 また，さきのクリープ試験においても，果実 は側部よりも果頂部が幾分硬いといら結果を示した。こ れは荷重方向が果頂部は果軸の方向, 側部は果軸に対し て直角の方向であることから考え, 果実の内部構造に起 因するものであると思われる.

第 6 図は堆積厚さ別の損傷程度を示したものである. 各品種ともに堆積厚さが厚くなるほど，損傷指数は高い 值を示した.

品種別に比較すると ' $\mathrm{H}-1409$ ' が最も高い損傷指数值 を示した. また，その損傷程度の変異も大きかった，次 

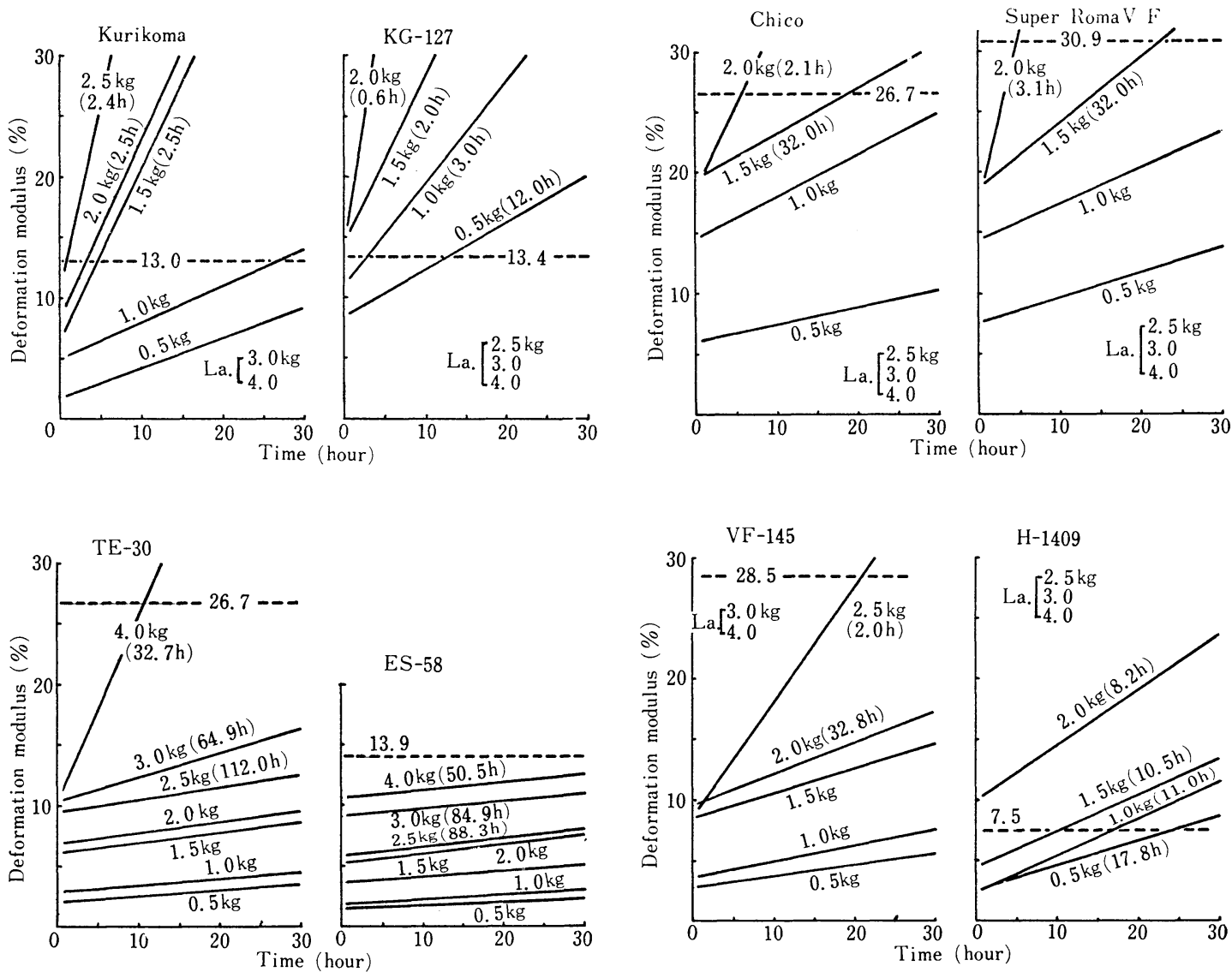

AT $70 / 24$
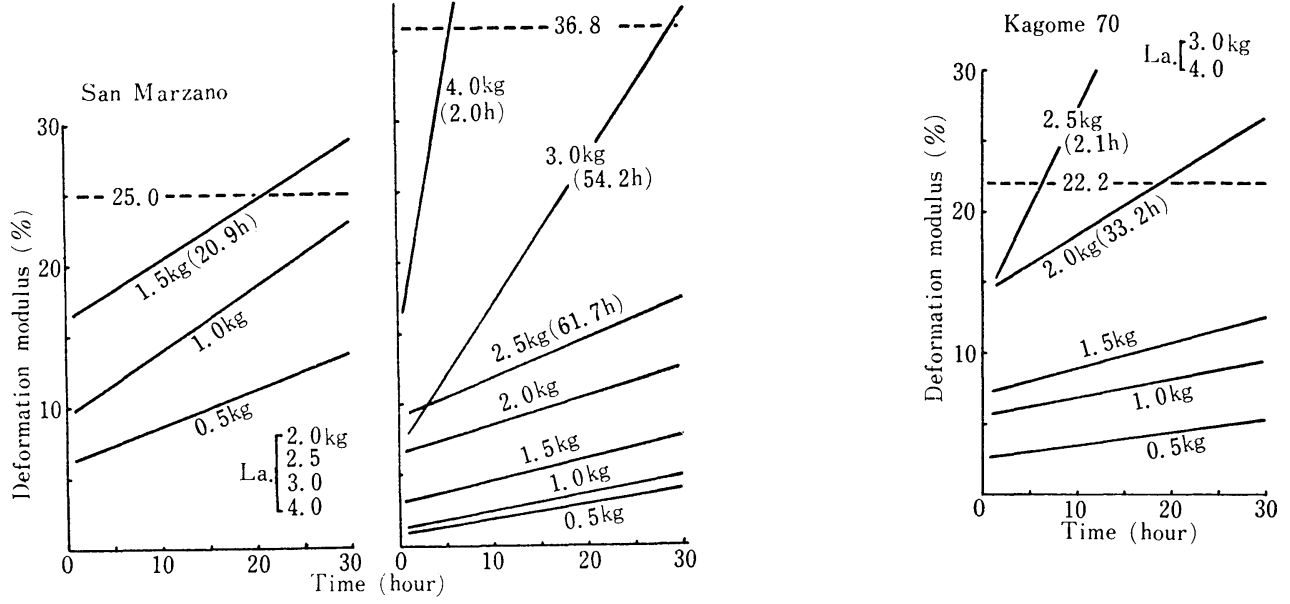

Fig. 4. Relationship of the degree of fruit deformation to the magnitude of load and to the loaded time in each cultivar.

-.... : Limiting deformation modulus

La : Laceration in a moment

( ) : Loaded time beyond which the fruits were lacerated. 


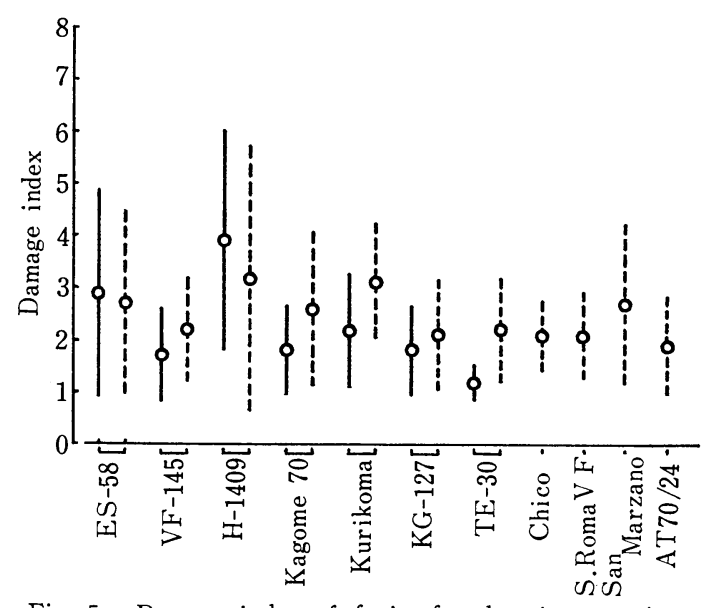

Fig. 5. Damage index of fruit after heaping practice with container for 24 hours.

- - - : Load from the top of the fruit -- - - : Load from the flank of the fruit

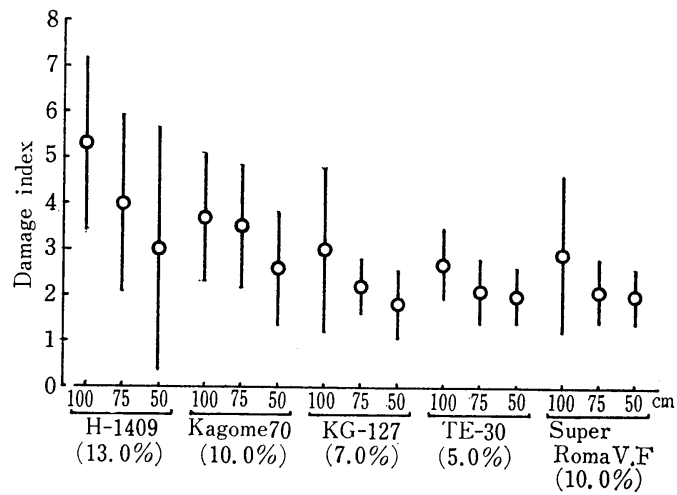

Fig. 6. Relationship between heaping height and damage index in each cultivar.

( ) : Sinking rate of heaping height after heaping practice for 24 hours.

いで‘カゴメ 70’の損傷程度が幾分大きい傾向にあった. 堆積厚さ $100 \mathrm{~cm}$ において, 24 時間堆積後の沈下率 は 'H-1409'が $13.0 \%$ を示し, 供試品種中では最も大 きかった。なお，‘TE-30’の沈下率は $5.0 \%$ にすぎな かった.

これらの結果は, 前述の試験結果からも認められるよ らに 'H-1409' の静圧荷重抵抗性は低く, ‘TE-30’に打 ける抵抗性の高いことを示唆している。

\section{考察}

一般に固体材料はすべてある応力限度以下，ある観察 時間内では十分な精度をもって弾性体とみなされる(11).

静圧荷重下における加工用トマト果実の挙動について 考えると，果実は荷重によって瞬間的に変形してしまわ ず，第 2 図の曲線にみられるような変形速度を保つ。そ
して荷重を取り除いたとき，変形は完全に元に戻ること はなく，永久変形を残す。これは粘弾性体のらち第 1 図 に示すような 4 要素模型のクリープ現象に酷似した。 こ のような傾向は河野ら（6）も認めている. また，石橋ら （1）は生食トマトで, Mohsenin ら(9)はリンゴで，中馬 ら(12) は温州ミカンで, 小島らはリンゴ(7), キュウリ (8)でも同様な傾向を認めている.

クリープ試験結果から，供試品種では 'AT 70/24' ‘TE-30’ 'ES-58’ が静圧荷重に対する変形率は小さく, $r_{1}$ は大きい值を示した，また， $\eta_{3}$ 值が大きく，残留変 形率は著しく小さかった。すなわちこれらの品種の果実 は硬く、さらに弾性的であろらと考えられた。

なお，さきに河野ら(6) は $\eta_{3}$ の大きい果実活ど耐振 動性が高いと報告した。これは果実の弾性によるものと 理解される.

静圧荷重に対する抵抗性について，果実の形態的性質 との関係から考察すると, 子室数が多く, 空洞の少ない, 比重の重い'TE-30’ 'ES-58’などの荷重に対する変形 量は少なかった。すなわち果実の構造からみて，中果皮 が厚く，胎座の発達が良く，子室に空洞がなく，ゼラチ ン様の内容物で充分に満たされている果実ほど，概して 変形量は少ないと言える.

成熟に伴って果実の硬さは漸次柔らかくなることが既 に明らかにされている $(3,5)$. 本実験でも同様な 結果が 得られた。 また，成熟に伴い $\eta_{3}$ の值は小さくなり，変 形回復率も順次小さくなる.すなわち果実は熟果ほど弾 性的挙動が劣るものと考觉られる.

荷重の大きさ別にみた負荷時間と果実变形量の関係か ら，果実の裂開損傷発生の状況をみると， 'ES-58’ ‘TE30' 'AT 70/24' の発生は少なく, 'H-1409' 'KG-127' ‘くりこま’に多い傾向が認められた。すなわち果実が硬 く, 弾性的挙動を示す品種ほど裂開損傷発生の少ないこ とが確認される.

第 4 図に示した直線の関係式から，荷重の大きさ別に 果実の裂開時点に打ける変形率を算出し, その平均值を 限界変形率と定めた. 各品種別の限界変形率は第 4 図中 に破線で示した.

限界変形率は ‘H-1409’が著しく小さい值を示し, $7.5 \%$ 程度の変形率で裂開損傷に達するものと考えられ る.したがって供試品種中では最も静圧荷重に対する抵 抗性の低い品種と言える. また, 限界変形率の大きい品 種は 'AT 70/24' 'Super Roma VF' 'TE-30' 'Chico' であった.これを‘AT 70/24’ ‘TE-30’が静圧荷重に対 する変形量の少ない品種であったことと併せ考えると, この 'AT 70/24' 'TE-30' にお㇒ける静圧荷重抵抗性は非 
常に高いと推察される.

次にこれらの実験結果から果実をバラ積みする場合の 安全な堆積厚さが問題となる.

堆積した果実の自重が下層にかかる荷重について, 静 水力学的に考察すると, 次式で示される $(11,13)$.

堆積による圧力は容器の形状及び大きさには無関係で あり, その厚さと単位体積の重さの積に等しい。いま, 堆積下層の果実 1 個に加わる荷重を $L(\mathrm{~kg})$, 最下層果 実上までの堆積厚さ $h(\mathrm{~cm})$ とすると, (1)式が成り立 つ. ここに・は単位体積の重さであり, 果実 1 個の平均 重量 $W(\mathrm{~kg})$, 果実の平均直径 $D(\mathrm{~cm})$ とすれば(2)とな る. (2)を(1)に代入し(3)を導く. (3)の移項式(3)に最下層 果実の平均径を加え, バラ積み堆積厚さ $H(\mathrm{~cm})$ は(4) 式となる.

$$
\begin{aligned}
L & =h \cdot r \\
r & =\frac{W}{D} \\
L & =h \cdot \frac{W}{D} \\
h & =\frac{L \cdot D}{W} \\
H & =\frac{L \cdot D}{W}+D
\end{aligned}
$$

ここに堆積時間を $20 \sim 24$ 時間と仮定し，第 4 図から

\begin{tabular}{|c|c|c|c|c|}
\hline Cultivar & Load $^{z}$ & Diameter & Weight & $\begin{array}{c}\text { Heaping } \\
\text { height }\end{array}$ \\
\hline & $\mathrm{kg}$ & $\mathrm{cm}$ & $\mathrm{kg}$ & \\
\hline Chico & $1.0-1.5$ & 4.39 & 0.054 & $\begin{array}{r}85.69-33 \\
126.33\end{array}$ \\
\hline Super Roma VF & 1.5 & 4.23 & 0.054 & 121.73 \\
\hline San Marzano & 1.5 & 3.81 & 0.047 & 125.41 \\
\hline $\mathrm{AT} 70 / 24$ & $3.0-3.5$ & 3.68 & 0.055 & $\begin{array}{r}202.74-\overline{2} \\
235.92\end{array}$ \\
\hline Kurikoma & 1.0 & 4.96 & 0.064 & 82.46 \\
\hline TE-30 & 3.5 & 5.86 & 0.107 & 197.54 \\
\hline $\mathrm{KG}-127$ & 0.5 & 4.38 & 0.051 & 47.32 \\
\hline ES-58 & 4.0 & 6.19 & 0.110 & 231.28 \\
\hline VF-145 & $2.0-2.5$ & 6.06 & 0.098 & $\begin{array}{r}129.73-65 \\
160.65\end{array}$ \\
\hline $\mathrm{H}-1409$ & 0.5 & 6.49 & 0.126 & 32.24 \\
\hline Kagome 70 & 2.0 & 5.21 & 0.066 & 163.09 \\
\hline
\end{tabular}
果実の裂開荷重を読みとり，上式によって果実の裂開し ない堆積厚さの許容限界を試算すると, 第 7 表に示すよ らに推定される。

Table 7. The permissible limit of heaping height.

堆積許容限界厚さはさきの実験結果において, 弾性的 な挙動を示した 'AT 70/24' 'ES-58' 'TE-30’ が著しく 大きい值を示した.すなわちこの結果からも，これらの
品種における静生何重抵抗性の非帘に吕いことが立証さ れる. 一方, 'H-1409' は $32.2 \mathrm{~cm}$, 'KG-127' は 47.3 $\mathrm{cm}$ の許容限界厚さであり，これらの抵抗性は著しく低 いものと考えられる.なお，この堆積厚さ許容限界の推 定結果は実際にコンテナを用い，あるいは層別に 24 時 間堆積処理した後の果実損傷度の調查結果からも同様な 傾向を伺うことができた。

以上の試験結果から，果実貯蔵法の合理化，すなわち 大型コンテナ, バラ積み法などの導入を考える上で, 滞 荷の回避は当然のことながら, 今後, 硬くて, 弾性的な 果実を有する品種の開発，育成が望まれる，本実験では 'AT 70/24’ ‘TE-30’ 'ES-58’ などの品種が 育種素材と しての有用性を具備しているように思われた。なお，果 実の硬さは果皮強度, 果肉硬度及び果肉率と密接な関係 が認められている(未発表, 5). したがって果肉率は子 室数, 隔壁の厚さなども当然関連している. しかし本実 験結果では果形指数, 果重, 体積, 比重及び子室数など の形質と弾性との間に明確な関係を把握することができ なかった，さらに弾性に関与する果実形質について解析 し，育種目標を明確にしてゆく必要があろう.

今回, 果実の静圧荷重抵抗性から堆積による貯蔵の適 応性を考察した。しかし収檴された果実が製造工程へ移 送される過程で果実は静圧荷重だけではなく, 同時に動 荷重をも受けるのが現状である. 今後, 収穫後の果実取 扱い法について検討する上で, さらに動荷重, とくに衝 撃荷重下における果実の挙動について究明する必要があ ろら.

\section{摘 、要}

加工用トマトにおける収穫後の果実取扱い法について 検討するため, 果実の静圧荷重抵抗性と堆積厚さの許容 限界について試験を行った.

1. 一定の静圧荷重下における加工用トマトの挙動は 粘弾性体のうち, 4 要素模型のクリープ現象に酷似した。

2. クリープ試験結果から, ‘AT 70/24' ‘TE-30' 'ES$58 ’$ の果実は硬く, 乙かも弾性的挙動を示す品種と考え られた。

果実のクリープ特性と色調 ( $\mathrm{a} / \mathrm{b}$ 值) との間には， 0.1 $\%$ 水準で高い相関関係があり, 果実の硬さ及び弾性的 挙動は成熟に伴い漸次低下することが確認された.

3. 荷重の大きさ, 負荷時間と果実変形量の関係から, 果実の裂開損傷の 発生は 'ES-58' 'TE-30' 'AT 70/24' で少なく，‘H-1409’ 'KG-127’ ‘くりこま’に多い傾向 が認められた.

裂開損傷に達する限界の変形率は 'AT 70/24' が最も 大きく, ‘H-1409’が最も小さい值を示した. 
4. 堆積厚さと果実の損傷程度との関係は堆積厚さが 厚くなるほど，損傷が大きかった。

供試品種にお村る果実損傷の発生程度は 'H-1409' が 最も大きく, ‘TE-30’が小さい結果を示した.

堆積許容限界厚さは 'AT 70/24' 'ES-58' 'TE-30'が 大きい值を示し, 'H-1409' 'KG-127’が小さかった.

以上の結果から, 果実が硬く, さらに弾性的挙動に富 む品種ほど, 静圧荷重に対する抵抗性は高いものと考元 られた。なお，供試品種中では 'AT 70/24/' ‘TE-30' 'ES-58’などが, 抵抗性品種育成のための育種素材を具 備しているよらに思われた。

\section{引用 文 献}

1. 石橋貞人.小島孝之, 1970. 農産食品の力学的性 質に関する研究 (第 2 報).トマトの生育, 成熟 および貯蔵中における機械的強度变化. 農機誌. $32: 59-64$.

2. 伊藤憲弘・寺田俊郎. 1977. 加工用トマト果実の 物理的性質に関する研究. 果実の色調について.

島根大農研報. $11: 5-11$.

3. 伊藤憲弘 - 寺田俊郎 - 高橋亮正. 1979. 加工用卜 マト果実の物理的性質に関する研究. 果実の形態 的性質と貫入抵抗力について．島根大農研報. $13: 12-20$.

4. 伊藤憲弘・寺田俊郎. 1981. 加工用トマト果実の 物理的性質に関する研究. 果実の落下衝撃抵抗性 について. 園学雑. 49:592-600.

5. 上村昭二・吉川宏昭・伊藤喜三男. 1973. トマ卜 果実の堅さ性に関する育種学的研究. 第 1 報. 果
実の堅さの測定法と堅さを支配する果実形質. 園 試報告. C $8: 13-25$.

6. 河野澄夫・岩元睦夫・早川 昭 -二宮英治・小林 一夫・木村 進. 1980. 加工用トマトの品種別輸 送耐性について。食工誌. $27: 143-148$.

7. 小島孝之. 石橋貞人. 1970. 農産食品の力学的性 質に関する研究 (第 3 報). リンゴ, ナシおよび モモの収穫後の強度変化. 農機誌. $32: 145-149$.

8. 小島孝之. 1975. 園芸生産物の物性に関する研究 (第 1 報). 久留米 $\mathrm{H}$ 型キュウリの形状および力学 的性質. 農機誌. $36: 549-554$.

9. Mohsenin, N. N. and Göhlich, H. 1962. Techniques for determination of mechanical properties of fruits and vegetables as related to design and development of harvesting and processing machinery. J. Agric. Engng. Res. $7: 200-315$.

10. 中川鶴太郎・神戸博太郎. 1959. レオロジ一. pp. 271，391一392. みすず書房. 東京.

11. 日本機械学会編. 1968. 機械工学便覧. 第 4 編. p. 7 , 第 8 編. p. 4 . 日本機械学会. 東京.

12. 中馬 豊 - 岩元睦夫 ·志賀 徹. 1971. 温州みか んの流通技術改善に 関する 研究 (第 3 報). 早生 温州の力学的性質とバラ輸送問題への適応. 農機 誌. $33: 304-311$.

13. 山下重良・森本純平. 宇田拡. 1979. 温州ミカ ンの選果荷造過程における損傷要因と損傷防止に 関する研究 (第 4 報). 果実に対する静生荷重と 堆積厚さの許容限界. 園学雑. $48: 367-373$.

14. 全国トマト工業会. 1971. 加工原料用トマトの検 查体制確立に関する実態調査. pp. 77-79. 